\title{
IDENTITY, CULTURAL TRANSNATIONALISM AND SECOND GENERATION JAMAICANS IN THE GREATER TORONTO AREA (GTA)
}

by

Serron Thomas, Honours Bachelor of Arts, University of the West Indies, 2011

\author{
A Major Research Paper \\ presented to Ryerson University
}

in partial fulfillment of the requirements for the degree of

\author{
Master of Arts \\ in the Program of \\ Immigration and Settlement Studies
}

Toronto, Ontario, Canada, 2015

(C) Serron Thomas 2015 


\section{AUTHOR'S DECLARATION}

I hereby declare that I am the sole author of this Major Research Paper. This is a true copy of the MRP, including any required final revisions, as accepted by my examiners.

I authorize Ryerson University to lend this MRP to other institutions or individuals for the purpose of scholarly research.

I further authorize Ryerson University to reproduce this MRP by photocopying or by other means, in total or in part, at the request of other institutions or individuals for the purpose of scholarly research.

I understand that my MRP may be made electronically available to the public.

Serron Thomas 


\title{
IDENTITY, CULTURAL TRANSNATIONALISM AND SECOND GENERATION JAMAICANS IN THE GREATER TORONTO AREA (GTA)
}

\author{
Serron Thomas \\ Master of Arts 2015 \\ Immigration and Settlement Studies \\ Ryerson University
}

\begin{abstract}
This study researches the impact that cultural transnationalism has on the identity of second generation Jamaicans in the Greater Toronto Area. Through a focus group interview, five participants provided responses to questions which identified (i) the components of cultural transnationalism in the Jamaican community, and (ii) how second generation Jamaicans create their identity between their Jamaican ancestry and Canadian nationality. The participants were asked about their relationship to Jamaican culture, Canadian identity, and their sense of belonging to both societies. Other themes which emerged from the data such as cultural values, exclusion and survival in Canadian society were also discussed.

The results showed that the second generation is prone to developing a hybrid identity which includes aspects of their national and cultural identity. To explain this phenomenon, I applied the research of Tajfel (1974) and Stryker (1980) which discuss the identity theory and social identity theory, respectively.
\end{abstract}

Key words: second generation, Jamaicans, Canadians, transnationalism, culture, identity, belonging, youth 


\section{ACKNOWLEDGEMENTS}

Firstly, I give heavenly thanks to Almighty God and all things positive for the strength to complete this major research paper (MRP). I dedicate this achievement to my dear deceased grandparents, Aggie Aguilera and John Bartholomew.

Secondly, I would like to extend great gratitude to my MRP supervisor, Dr. Vappu Tyyskä, for all her patience and support throughout this journey. Vappu, I am honored to have shared this experience with you and enjoyed our time spent together; you are truly inspiring. I would also like to extend gratitude to my second reader, Dr. Camille Hernandez-Ramdwar for reading my MRP and providing her expertise.

Thirdly, I would like to thank all research participants and persons who showed interest in my project. Thank you for sharing your beliefs and opinions with me; I am truly grateful for your cooperation, time and efforts.

To my family and friends; thank you for your words of encouragement. Thank you to my mother for her unwavering support and many thanks to my niece and nephews for inspiring this research idea. Thank you to my supportive brother, sisters, aunts, uncles and cousins for constantly cheering me on; you kept me going. To my dear friends, Donnalla Adams and Steven Taylor, thank you for every prayer and stern show of support. Special thanks to you, Junior Rainford, for all your assistance given throughout this project; you are one of a kind.

Finally, to my University of the West Indies (St. Augustine) undergraduate professors, Louis McWilliams and Roddy Batchasingh; thank you for believing in me. To everyone else who wished me well and encouraged me along the way, I thank you from the bottom of my heart. It has been a long journey and your support was highly appreciated. 


\section{TABLE OF CONTENTS}

Author's declaration $\quad$ ii

Abstract $\quad$ iii

Acknowledgements iv

Introduction 1

Literature Review 3

Transnationalism and the Second Generation 3

Causes and effects of transnationalism among the 4 second generation

Social Identity Theory- Group Identity and the Self 9

Identity Theory- Role Identity and the Self 11

Methodology 14

Research Method 14

Selection $\quad 15$

Research sample and focus group process 15

Data analysis method 16

$\begin{array}{lr}\text { Results } & 18\end{array}$

$\begin{array}{ll}\text { Being Jamaican } & 18\end{array}$

$\begin{array}{ll}\text { Cultural values and norms } & 18\end{array}$

Jamaican food 20

Jamaican music and language $\quad 21$

$\begin{array}{ll}\text { Jamaican festivals and colours } & 23\end{array}$

Family and the Jamaican bloodline $\quad 23$

Visiting Jamaica $\quad 24$

Being Canadian $\quad 26$

Sense of Belonging $\quad 27$

Identifying Oneself $\quad 30$

Analysis and discussion $\quad 33$

Cultural Transnationalism in the Jamaican Community 33

Second generation Jamaican Identities and Cultural 34

Transnationalism

Group-based identity v role-based identity 34

Cultural upbringing, ancestral pride and hybrid 37

identities

Belonging, exclusion and survival $\quad 39$

Conclusion $\quad 43$

Limitations and Further Research $\quad 45$

Appendix

47

References $\quad 48$ 


\section{Introduction}

Transnationalism occurs when there is a "forging and sustaining [of] familial, economic, cultural, and political ties and identities that cross national borders" (Guarnizo \& Smith in Leitner \& Ehrkamp, 2006, p. 1615). The term is used to categorize the social processes created between immigrants and their home societies during integration in the receiving society (Wong, 2007). Initially, this phenomenon was attributed to the first generation only but recently, research focus includes other generations since it was realized that transnationalism does not end with the

first generation (Somerville, 2008; Lee, 2011). Somerville (2008) purported that transnationalism is not a one-generation phenomenon; rather, the second generation is being raised in a “transnational social field" (p. 30). In support of this perspective, I have decided to explore the relationship between second generation Jamaicans, identity and cultural transnationalism. I will observe how second generation Jamaicans in the Greater Toronto Area (GTA) create their identities between a Canadian nationality and a Jamaican ancestry. Additionally, my research will focus on the impact that cultural transnationalism has on this process.

Generally-speaking, cultural transnationalism refers to the "collective enjoyment of cultural events and goods" which reinforces a sense of identity with the ancestral country (Portes, Guarnizo and Landolt, 1999, p. 221). Using this explanation as a guide, I will create a complete definition of cultural transnationalism for my research by incorporating specific cultural events and goods of the Jamaican diasporic community. I chose this diasporic community because I wanted to focus on a Caribbean-based community and Jamaica currently has the largest immigrant population from the English-speaking Caribbean in the GTA (National Household Survey profile, 2014). 
To understand the development of identity and how transnationalism impacts this process, I have relied on the identity theories of Tajfel (1974) and Stryker (1980). The identity theory and social identity theory have discovered and discussed the processes by which one's identity is created and although their perspectives differ, it is agreed that an understanding of self-conceptualization is critical when discussing the creation of one's identity. These theories are crucial for understanding identity development and have provided the foundation of later studies. They will be used to guide my research; however, data collected will also be presented according to themes emerging directly from my research. Below, I will review literature on transnationalism and the second generation to gain an understanding of the cause and effect of transnationalism on the second generation's identity. This will be followed by a brief explanation of the major aspects of the social identity theory and the identity theory. Thirdly, I will reveal my research method and share my qualitative data. Finally, my findings will be discussed, analyzed and then, conclusions will be drawn. 


\section{Literature Review}

\section{Transnationalism and the Second Generation}

Studies on the second generation of different communities have revealed that the second generation is highly engaged in transnational activities. Like the first generation, scholars have

identified that the identities of second generation individuals are impacted by these transnational habits (Plaza, 2006; Kasinitz et al., 2002). Generally, the second generation displays varying degrees of involvement in sending remittances and visiting their parents' home countries, participating in home-country politics and engaging in home-country media. Together, these activities demonstrate the economic, familial, political and cultural aspects of transnationalism. Lee (2011) insists that,

Rather than imposing a typology based on assumptions about what constitutes transnationalism, it might be more useful to look at what kinds of ties are most highly valued by different diasporic communities (p. 300).

Using this suggestion as a guideline, I will focus on aspects of the Jamaican culture which are deemed highly valuable in the Jamaican diasporic community. These aspects will be used to discover what constitutes cultural transnationalism in the Jamaican community. In examining Jamaican communities, Mordecai and Mordecai (2001) noted that Jamaican art, language and social customs exist beyond the first generation of immigrants within the host society. These features are highly important to the Jamaican diasporic community and play an active role in the preservation of the Jamaican culture overseas. As a result, this analysis will focus on the second generation's affiliation to Jamaican food, music, language, and Jamaicanthemed events in the GTA. Cultural transnationalism may also constitute forms of cultural 
knowledge; hence, Jamaican cultural norms and values will also be incorporated into the analysis (Lee, 2011).

Causes and effects of transnationalism among the second generation. The ease of access to the parents' home countries is one of the reasons used to explain the persistence of transnational activity within the second generation across different communities (Kasinitz, Waters, Mollenkopf and Anil, 2002). Recently, due to the development of technology and increased globalization, the second generation is more likely to visit the parents' home country. While this increase of mobility to the parents' home country may have an impact on the degree of transnationalism that the second generation engages in, it is noted that actual mobility across countries is not necessary for an individual to be considered transnational (Lee, 2011; Kasinitz et al., 2002). In a study on the Tongan second generation in Australia, Lee (2011) identified that transnational activity occurred without the second generation visiting Tonga. Her study supports the belief that a person can be transnational without engaging in physical movement between the home and host countries.

For members of the second generation, who may never have been to their parents' homeland, the question [of whether or not a person can be transnational without movement between the countries] is particularly salient. This issue of what truly constitutes transnationalism resonates with arguments about cultural identity and authenticity, which often involve judgements about authentic identity based on particular forms of cultural knowledge (Lee, 2011, p.297).

The study uncovered how the second generation Tongans engaged in transnationalism by describing three forms of transnationalism: intradiasporic, indirect and forced. 
Intradiasporic transnationalism, the ties maintained across different diasporic populations, can occur independently of the host-home connections that are the primary focus of transnational studies. Some members of those diasporic populations do not engage in any direct transnational ties at all, yet their indirect involvement through practices such as contributing to family remittance pools, fundraising activities and church donations ensures that they remain enmeshed in transnational webs of connection. This indirect transnationalism can include involuntary involvement, or forced transnationalism, a term that also describes practices such as sending children and youth from the diaspora to the homeland against their will (Lee, 2011, p. 295)

Somerville (2008) adds to the argument that transnationalism is not a one generation phenomenon, by researching second generation Indians in Canada. Findings from her study support the argument that the second generation is growing in a transnational social field and indicates that communication technology plays a major role in expressions of transnationalism. The development of technology has allowed immigrants to remain closely connected with their families who reside in the home country. As a result, this constant communication becomes contributory to the development of transnational behavior within the second generation. While some second generations may visit their parents' home countries, it is not necessary to do so to obtain a close connection to the home country; rather, a transnational network is often created using technology. The second generation is provided with the opportunity to learn about their parents' home country through immediate contact with relatives in the home country, using technology. Access to social media sites, cell phone apps and video-calling services such as Skype, allow individuals to experience living in both worlds without actual mobility occurring. 
The second generation is maintaining cross-border communication through internet, phone calls and visits. Through regular contact with friends and family, the second generation are connected physically and emotionally to more than one country (Somerville, 2008, pp. 30 - 31).

Another contributory factor to transnationalism exists within the household and community in which the second generation individual is raised. As globalization continues to play a role in the opening of borders across countries, the concept of a hybrid identity has become more acceptable in some societies. Plaza (2006) has indicated that in Canadian society, the development of hybrid identities is promoted because of the country's adoption of multiculturalism policies. As a result, individuals feel encouraged to maintain the customs and culture of the home country while residing in the Canadian society. This continued connection to the home country allows immigrants to convert their social spaces into cultural hubs which foster the growth of transnational activity. As noted by Lee (2011), transnational activity also refers to cultural knowledge and engagement in cultural activities. Similarly, Plaza (2006) recognizes that the second generation's involvement in cultural activities and norms, as well as other transnational connections provide them with a satisfying sense of the home country. In Toronto, numerous cultural events serve to reinforce a sense of the home country's identity among immigrants. Festivals such as Salsa on St. Clair (which celebrates the food, music and dance of the Latino community), and Caribana (which celebrates the Caribbean's art and music), serve to strengthen the Latino and Caribbean second generation's appreciation and understanding of their parents' home country.

By participating in a Caribana mas troupe in Toronto, speaking patois with a bona fide accent, eating Caribbean cuisine, or listening to popular reggae music, one-and-a-half- 
generation and second generation Caribbean Canadians have come to feel as though they have had an authentic cultural socialization to use the label on themselves-Jamaican Canadian, Trinidadian Canadian, Guyanese Canadian, and so on, depending on the circumstance (Plaza, 2006, p. 214).

Plaza (2006) shows that the second generation is likely to develop a blended or hybrid identity which highlights the strength of their transnational linkages. Although they are raised in Canadian society and engaged in Canadian social systems, the second generation may choose to maintain a partial identity with their parents' homeland. This choice may be affected by the individual's sense of belonging. Research shows that while the second generation may maintain a hybrid identity, they are more likely to identify strongly with where they feel a sense of belonging. In the case of Jamaica, Hall (2010) noted that the portrayal of Jamaican language and art plays a significant role in developing a sense of belonging among Jamaican immigrants. These aspects of the Jamaican culture are used to "fend off a sense of displacement" within the host societies and serve to provide immigrants with a sense of belonging to Jamaica (Hall, 2010, p. 136). While this sense of belonging may be viewed as imagined for second generation individuals who have not visited Jamaica, Hall (2010) asserts that "home" is not always a physical space; rather, it is an idea which constitutes identity and cultural solidarity. Therefore, it is possible that the second generation may feel a sense of belonging to their parents' home country although they have never visited or directly experienced it. This can occur despite being born and raised in Canadian society. Additionally, Jedwab (2007) purports that it is not guaranteed that individuals will portray a strong sense of 'Canadianness' because they possess Canadian citizenship and were raised in Canadian society. He believes that individuals should not feel obligated to link their citizenship to their sense of belonging (Jedwab, 2007). Instead, he 
sees transnationalism as an opportunity for individuals to identify with whichever community and culture they wish. While possession of dual citizenship may increase the possibility of transnationalism, Jedwab (2007) warns that citizenship and a strong sense of belonging to the country should not be linked. He does not believe that identification with another culture or community detracts from a person's national identity:

There is no doubt that many people associate their citizenship with their sense of belonging to Canada. Moreover, the federal government is well within its right to support a sense of belonging to Canada amongst its citizens regardless of whether they are single or dual. However, the federal government should not tie citizenship to a strong sense of belonging to the country. While it may be regrettable, citizens of Canada have the right to not feel a strong sense of attachment to the country. Such an idea runs counter to Canada's central role in the promotion of cultural diversity abroad and in so doing risks inadequately reflecting the diverse peoples we are (Jedwab, 2007, p. 66-67).

As a result, it will be inadequate to investigate the 'Jamaicanness' of Jamaican second generations in Canada, without acknowledging their 'Canadianness'. Howard's (1998) study about 'Canadianness' has indicated that children of immigrants tend to identify with Canadian society, once they have little or no connection to the native homeland. Based on interviews conducted with first-generation immigrants who gained citizenship, Howard (1998) concluded that "individuals normally identify as part of the society in which they grow up [and] not as members of ancestral societies with which they may have had little or no contact” (p. 134). Although Howard's findings are indicative of these actions, it should be acknowledged that Canada has traditionally promoted a dual-citizenship, multicultural society and these conditions may have an impact on how an individual's identity is constructed. Hence, studies have revealed 
that a fusion between the ancestral and national identity is ideal in the Canadian society, since it provides individuals with the fluidity that is desired in a multicultural society. For example, Simmons and Plaza (2006) highlighted that

Multiculturalism policies in Canada have encouraged many young Caribbean Canadians to live between two worlds where national boundaries, national cultures, and national identities are flexible. Many young men and women have been able to avoid feeling absolute pressure to follow a single linear assimilation path in Canada (as cited in Plaza, 2006, pp. 213-214).

Although the strength of the second generation's connection to their ethnic identities and transnational behaviours differ across diasporic communities, it is important to investigate these relationships and the roles they play in constructing second generation identities. As the above studies have shown, transnationalism has an impact on the development of one's identity despite the lack of mobility between countries and the acquirement of citizenship in one's country of residence. The development of one's identity, however, is influenced by other factors throughout one's life. For the purpose of this paper, I will look at how the self is conceptualized using group-based and role-based attributes. The following section outlines the social identity and identity theories which, as mentioned earlier, will be used to guide my research.

\section{Social Identity Theory- Group Identity and the Self}

Our identity may simultaneously distinguish us from each other while highlighting our similarities. Although each person possesses his or her own identity, it is purported that the concept of a 'group identity' occurs because of perceived similarities among individuals (Hogg, 2007). Based on the social identity theory by Henri Tajfel (1974) self-categorization is the term 
used to explain the process where individuals classify themselves using the attributes of a group (Hogg, 2007). According to Hogg (2007), individuals may categorize themselves based on a group's attributes rather than on their own attributes. While the theory claims that the self contains two levels of identity (personal and social levels), the personal level of identity is usually overridden when the individual categorizes his/her identity according to the group's attributes (Stets \& Burke, 2000). This categorization ultimately results in a stereotypical expectation of who the individual should be and how he/she would behave. While this method creates the identity of the individual, it also shapes the individual's perception of others. Using the process of inclusion and exclusion, members of a group determine that those who do not fall into the group's criteria cannot be included in the group (Hogg et al, 1995; Hogg 2007). Every group has its own set of criteria to be met and persons who identify with their group-based identities tend to abide by the expectation of the group. Examples of this type of categorization are seen daily, for example, at sporting events. At sporting events, each team comprises of a group of people who identify with the same goals, purposes and culture. As a member of the team, an individual will adopt the perspective of the group and will highly participate in groupbased activities (Stets \& Burke, 2000). Individuals who adhere to the team's perspective are viewed as teammates, whereas those who differ are deemed opponents. The result is a tension between the teams, since both believe that they are superior to the other.

In society, self-categorization is also used to differentiate different races, cultures and ethnicities. Individuals may classify themselves according to the criteria of their race, culture or ethnicity while believing that those who do not meet the selected criteria will not belong (Hogg et al, 1995). Through social comparison, the self is able to identify similar persons as members of the 'in-group' and everyone else as members of the 'out-group'. This form of grouping further 
creates an 'us vs them' mentality whereby the in-group is viewed positively while the out-group is viewed negatively (Stets \& Burke, 2000).

The social comparison component of this theory raises some pertinent questions. For instance, can someone of mixed races or cultures identify themselves with multiple racial or cultural groups? If so, how does this work if maintaining a group-based identity means excluding the prescribed attributes of other groups? Although the social identity theory suggests that there are levels of identity within the self, it does not address the ownership of multiple group-based identities. This lack of acknowledgement indicates that the social identity theory perceives the group-based identity as singular. In response to the belief that one's identity is singular; Hall (1996) argued that,

The life of an individual is never stable, fixed or unified. Identities are fragmented and fractured, never singular but multiply constructed across different, often intersecting and antagonistic, discourses, practices and positions (p. 4).

This perspective suggests that individuals can possess a fluid identity which transcends the exclusionary attribute prescribed upon them within their groups. The possibility that multiple and hybrid identities may develop during the construction of one's identity is noted for this study. Additionally, identity theory supports this multifaceted feature of the self and it will be explained in the following section.

\section{Identity Theory: Role Identity and the Self}

A slightly alternative view of identity conception is discovered in identity theory. While social identity theorists insist that identity is conceptualized through group-based identities, identity theorists believe that individuals identify according to their roles in society. Rooted in a 
symbolic interactionist theoretical framework, identity theory presupposes that "society shapes self, which shapes social behavior" (Stryker \& Burke, 2000, p. 285; Stryker, 2001). This means that the social structure of society and the roles given are seen as the defining factors in the creation of one's identity. In identity theory, individuals behave according to or identify with the roles that they are assigned in society. The meanings of these roles are acquired through interaction with others in society and are portrayed through corresponding behaviors. With its foundation in symbolic interaction theory, this theory does not support the view that society is unitary; rather, identity theory recognizes that the self may possess multiple identities due to the assignment of many roles. Once claimed, each role is given a corresponding identity and different identities may be used in different situations (Burke \& Stets, 2009; Stryker \& Burke, 2000; Stryker, 2001). An example of this identity selection can be seen in a scenario where an individual works multiple jobs. At one job, he may be an office manager, while at the other; he may be a school bus driver. In each situation, this individual presents a different identity to those around him. As a result, the identity which corresponds to the role in the situation becomes dominant and influences the individual's behavior. This acknowledgement of multiple identities is another notable difference between identity theory and social identity theory. In identity theory, a contemporary image of society is incorporated and this image promotes multifaceted dimensions, which create a versatile effect on the self (Stryker, 2001). It recognizes that,

Self is conceptualized as comprised of a set of discrete identities, or internalized role designations, with persons potentially having as many identities as there are organized systems of role relationships in which they participate (Stryker 2001).

While the main premise of this theory is the self's ability to select identities and corresponding behaviors according to their roles in society, it is important to note that this 
decision can occur knowingly or unknowingly. At times, individuals may not be aware of their identity processes but the self will choose a role identity which is most appropriate to the situation. The self will then retain this selection for future situations where this role is applicable. This is referred to as automatic processing and although individuals may not focus on its occurrence, the self maintains control of the identity process (Burke \& Stets, 2009).

We are not suggesting that people are necessarily aware of and consciously controlling their identity processes, only that control is present, whether conscious and deliberate, or habitual and without much thought (Burke \& Stets, 2009, p. 61)

Furthermore, a person's commitment to a particular identity plays a factor in whether or not the identity becomes dominant or automatic. Hogg et al (1995) purported that "the number and importance of social relationships" associated with the identity increases the commitment and salience/significance of the identity within the self (p. 258). In other words, the most important role is given preference during the identity selection and the individual will behave accordingly.

Since both identity and social identity theories are critical to the understanding of how identities are created, there is a possibility that either can provide my research findings with a theoretical explanation. The next section will outline the research method that will be used to retrieve data for my study. Due to limited scope of my paper, I will not be able to make general conclusions about the second generation Jamaican community in the GTA; rather, data uncovered will be representative of the research conducted. 


\section{Methodology}

\section{Research Method}

My research explores the creation of second generation Jamaican identities and the impact cultural transnationalism has on this process. To address this concern, I sought answers to the main questions: i) What constitutes cultural transnationalism in the Jamaican community? ii)How do second generation Jamaicans in the GTA develop their identities? and iii) What impact does cultural transnationalism have on this process?

To answer these questions, I used an interpretive approach which allowed for the exploration of multiple realities (Neuman, 2011a). I applied qualitative research methods to ensure consistency with my interpretive approach and relative epistemology. Given the time constraints, I decided to use a small research sample which can be efficiently explored through the use of a focus group. Contrary to the restrictive characteristics of surveys and questionnaires, a focus group allows individuals to express their opinions freely and facilitates discussion (Neuman, 2011b). It encourages participants to query one another's perspectives and provides the participants with a sense of empowerment (Neuman, 2011b). Furthermore, this method allowed me to locate the multiple realities and interpretations that participants may have about this topic.

While there are advantages to using a focus group for my study, limitations are also noted. Neuman (2011b) points out that "a moderator may unknowingly limit open, free expression of group members" (p. 460). To decrease the occurrence of this limitation, I continuously encouraged participants to express their opinions freely without fear of judgment. One focus group consisting of five participants was conducted. The focus group interview was semi-structured, which means that the participants were asked open-ended questions and they were not restricted to selecting pre-determined answers. Open-ended questions allowed participants to respond openly to questions and fostered additional discussion about the topic 
(Neuman, 2011). I asked a prescribed set of questions which facilitated conversation throughout the session but also incorporated probing questions which arose from participants' responses. Refreshments were provided as minor incentives for participants' contribution to this study.

Selection. Participants were Canadian-born, second generation Jamaicans between the ages of 18-35 and reside within the Greater Toronto Area (GTA). For selection purposes, no distinction was made across the different racialized groups within this community; selection criteria were based on the individual's second generation status, sex and age. I used a combination of snowball and purposive sampling to ensure that participants fit the criteria requested (Neuman \& Robson, 2012). I decided to use a combination of snowball and purposive sampling because snowball sampling allowed me to locate potential participants through the networks of people and/or organizations, while purposive sampling allowed me to select persons who strictly met the participant criteria of the study (Neuman \& Robson, 2012). Emails were sent to individuals and organizations with information about the study, in an attempt to recruit participants. Posters were also created to advertise the study and additional information was distributed accordingly. Once interest was indicated by potential participants, a screening was done using the screening criteria form and then, the selected persons were provided with the consent form to review. Upon signed agreement of the conditions outlined in the consent form, the selected persons were invited to attend the focus group session.

Research sample and focus group process. The research sample consisted of five participants: two males and three females (see Appendix 1 for demographics table). All participants had single Canadian citizenship and resided in different parts of the GTA (Toronto, Scarborough, Markham, Ajax). Both parents of each participant were Jamaican-born and immigrated to Canada during adulthood. Although membership in specific racialized group was not part of the selection criteria for the study, all participants ended up being of Africandescent/black, and all acquired a university education. 
The focus group took place at $12: 30 \mathrm{pm}$ on July $25^{\text {th }} 2015$. It lasted approximately two hours and took place at a secure, quiet location. Participants were provided with snacks and beverages to make them feel comfortable in the space. The presence of Tim Horton's donuts and Jamaican patties immediately started a casual conversation among the participants and these snacks were strategically selected for this purpose.

At the start of the focus group, I introduced myself and the topic of the study. I explained the importance of confidentiality to the participants and reassured them that their opinions will be respected. Following this, the participants were given the consent form and demographic form to fill. They were asked to choose a pseudonym to help protect their identity and as added protection, throughout this paper, I will refer to the participants by the initials of the chosen pseudonym. Additionally, no cell phones were allowed in the focus group space and participants were required to place their cell phones on silent. The focus group interview was audio-recorded and transcribed.

Data analysis. At the start of the study, a literature review was conducted to acknowledge theories that are relevant to the topic. This knowledge was used to guide my ideas; however, using the grounded theory method, I remained open to additional themes which emerged during my analysis. The grounded theory method "adds flexibility" and encourages researchers to "build theory from the data" and allows "the data and theory to interact" (Neuman, 2011c, p. 175). As a result, I anticipated theoretical connections within the literature review and data.

To analyze the data received, I firstly recorded and transcribed the participants' answers. Following this, the data was read and coded to identify themes and patterns evident in the responses. Then, data was categorized according to the themes present. This was done in three stages: open-coding, axial coding and selective coding. Neuman (2011d) explained that, 
The first coding [open-coding] of qualitative data examines the data to condense them into preliminary analytic categories or codes. [During axial coding,] the researcher organizes the codes, links them, and discovers key analytic categories. Selective coding [is] the last stage in coding qualitative data. [It] examines previous codes to identify and select data that will support the conceptual coding categories that were developed (pp. 511-514).

To code the data, I looked for repetitive statements, connections to theories and other relevant information. The created categories of information were then connected and analyzed to reveal the main results of the study. 


\section{Results}

The data from the focus group interview revealed three main themes: i) Group-based identity v role-based identity; ii) Cultural upbringing, ancestral pride and hybrid identities; and iii) Exclusion, belonging and survival. The responses which created these themes and sub-themes will be discussed in this section. To do this, I will state the corresponding question and provide the results that followed. As mentioned, the purpose of the focus group interview was to understand how second generation Jamaicans in the GTA form their identities and how cultural transnationalism affects this process. This understanding was achieved by asking the research participants four main interview questions: i) What does it mean to be Jamaican? ii) What does it mean to be Canadian? iii) Which society do you have a sense of belonging to and why? iv) How do you identify yourself?

\section{Being Jamaican}

At the start of the interview, the participants were asked about what it means to be Jamaican. The themes cultural upbringing and ancestral pride arose from these responses. Aspects of cultural upbringing will be discussed in five sections: values and norms, Jamaican food, Jamaican music and language, and Jamaican festivals and colours. The importance of ancestry and visiting Jamaica were also mentioned as part of the definition for being Jamaican.

Cultural values and norms. All participants insisted that the values and norms bestowed upon them throughout their childhood play a major part in defining what it means to be Jamaican. In response to this question, $G$ (female, 29) and X (male, 35) stated that: 
For me being Jamaican is culture because I grew up with Jamaican parents who have Jamaican ideals and that's what they passed on to me. (G., personal communication, July $25,2015)$

Sort of just a pride, your upbringing, your pride of where you came from. The pride to say, "Hey, this is our sort of unique culture, this is what Jamaicans bring to the table". (X., personal communication, July 25, 2015)

When asked about why his Jamaican culture is acknowledged although he is born and raised in Canada, X added that "It's a cultural thing; it's how you were raised. I am second generation with Jamaican parents" (personal communication, July 25, 2015). Others supported this perspective by highlighting that they were also raised according to the values of the Jamaican culture and think that these values are crucial to the development of their "Jamaicanness". Of these values and norms, the desire to "work hard" and maintain good family ties are prominent.

Most participants agreed that it was important in a Jamaican household to wake early and maintain a strong work ethic. W (female, 35) stated that:

My mum and stepdad are both Jamaican and my stepdad enforced a lot of the Jamaican culture that he grew up with on most of my siblings. You would get up early, if you wanted to stay up late, you will still get up early and do your chores, you got to come help the family business, you got to come work. So we did a lot of that, they instilled a lot of what they learnt in us. (personal communication, July 25, 2015)

$\mathrm{G}$ (female, 29) attributed her desire to work from an early age to being raised in a similar setting. She explained that: 
I started working when I was 12 by choice because it was so natural because my parents were so hard-working; it was just something we did. When I started working my first job was selling chocolates and I was the youngest person selling chocolates door to door. Then I decided that job wasn't enough so I got another job; I started babysitting three children. I was juggling these two jobs at 12; it was ridiculous. Now, I look back and it's hilarious and I gave my mum some of my money. (Laughter) It was crazy but it was natural because that's just what we did. (personal communication, July 25, 2015) This work ethic is also found at the academic level. All participants agreed that the encouragement of academic success is a major component of the Jamaican culture.

E.R. (female, 34) shared that her parents made education a priority in the household. She stated that,

My mother and father think that if you didn't excel, it was a form of embarrassment. A lot of my family members felt the same way... If I got a D, it was embarrassing or when we go to parents' night [at school]. My mum was very concerned about being embarrassed or bringing shame upon the family. Work hard, get good grades; it was embarrassing if you were a dunce or last in your class. (personal communication, July 25, 2015)

All participants agreed that a successful education was important to them and their families.

Jamaican food. All participants eat or cook Jamaican food although they regard it as time-consuming to prepare. A conversation about Jamaican food ensued and the participants stated: 
I think that I eat more of the Canadian-type food because it's more bland and easier to prepare but I do enjoy Jamaican food. On weekends, I will definitely make an effort to make a meal more Jamaican-based, once I'm home. (X., personal communication, July $25,2015)$

I love the Jamaican food but it takes time and I don't like buying Jamaican takeout either. (G., personal communication, July 25, 2015)

A.M. (male, 35) also agreed that preparing Jamaican food is time-consuming, however, he avoids cooking it by finding restaurants which provide him with Jamaican meals:

So, I agree with you, G. I find my 'hits' [Jamaican restaurants] and I stay with them. For example, I have a place for jerk-chicken and I only go to that place for jerk-chicken. I have a place for my oxtail, I have a place for my roti and I go to those places. No adlibbing, I just stick to the script. (A.M., personal communication, July 25, 2015)

Jamaican music and language. With regard to music and language, the participants had varying responses about their involvement. Four of the participants acknowledged that they listen to Jamaican music while one expressed that "it was strange for me to like it" (A.M., personal communication, July 25, 2015). One participant indicated that she was aware of the Jamaican dancehall dances when she was younger; however, she is not presently interested in learning the dances.

When asked about the ability to speak the Jamaican language called 'patois', the participants laughed. All participants indicated that they understand the language but cannot speak it fluently. G (female, 29) suggested that: 
I feel like the second generation, at least the people I know; there's been an evolution of language. There are slangs that the second generation would use that my parents would never know what that means but it has basis in the Jamaican patois. A lot of Toronto slang is based in patois. Most of the words that everybody uses.... e.g. "Yuh dun Know" and all types of stuff. A lot of what other cultures are using is based in Jamaican patois in Toronto so I think it had a huge influence on slang. I think everybody uses the patois without even knowing it (personal communication, July 25, 2015).

Additionally, this participant revealed that some of her Jamaican relatives do not speak or understand patois:

Some Jamaicans don't speak patois, like my mum's family; they never spoke patois. Where they lived, they spoke the Queen's English so my mum doesn't know how to speak patois at all. One of my aunt's husbands speaks very quickly [in patois] and I usually translate so that my mother can understand. She does not know what he is saying at all (G, personal communication, July 25, 2015).

Other participants also mentioned instances where their parents spoke the "Queen's English" rather than engage in patois.

For my mum, it depends on who she was talking to. If she got a very important phone call then she would be very "speaky-spokey" where she would talk like she is the queen so that people could understand her. If it was a friend, among siblings or in a room full of Jamaicans, they would talk non-stop patois. It depended on what the situation was (E.R., personal communication, July 25, 2015). 
Jamaican festivals and colors. The participants were quite familiar with Jamaican and Caribbean cultural events in the GTA. They revealed that they attended some events throughout their childhood and some participants continue to do so presently. The 'Jambana', 'Caribana' and 'Jamaica Day' festivals were among the few mentioned by these participants. Two participants highlighted that they attend Jamaican cultural events regularly while everyone else admitted that they do not attend. A.M. (male, 35) disclosed that, "I haven't been in years. I remember going as a kid and I didn't like it. It [Jambana] was a rollercoaster" (personal communication, July 25, 2015). Others expressed that they do not attend because they do not feel the desire to do so. E.R. (female, 34) proudly stated that:

I attend here and I also attended one in Jamaica. Normally, I go to music festivals. In March, I attended a week-long track and field competition called Champs, in Jamaica. I find myself often yearning to go frequently. I've already gone twice for the year and I am itching to go again (personal communication, July 25, 2015).

Upon attending cultural events however, the participants admitted that they show their Jamaican pride by displaying the Jamaican flag and national colors. Some participants mentioned that they carried the Jamaican flag when they attended Caribbean events locally and internationally. Additionally, other participants agreed that the Jamaican flag or colors can be found either in their vehicles or in their homes.

Family and the Jamaican bloodline. Added to the definition of being Jamaican, is the importance of family and the Jamaican bloodline. The participants believe that the Jamaican bloodline is a primary aspect of the Jamaican identity. When asked about accepting someone as Jamaican, G (female, 29) insisted that "if they are born to Jamaican parents, they are Jamaican" 
(personal communication, July 25, 2015). This importance of the Jamaican bloodline is further demonstrated by statements from X (male, 35) and E.R. (female, 34) respectively: "Family firstBlood is beyond most things out there" and "You can't erase the bloodline" (personal communication, July 25, 2015). They do not agree that the engagement in cultural elements such as Jamaican food, music, language and Jamaican-themed events is a primary substantiation of Jamaican identity. Instead, the participants agreed that less or no involvement in these cultural activities do not make a second generation Jamaican, less Jamaican. G (female, 29) purported: I think a cultural identity stands beyond food, music, dancing. It spans so much deeper than that, for example, it's your upbringing and values. There are things that are much deeper than the physical. I know people who are Jamaican who don't eat Jamaican food or like Jamaican music but they grew up with Jamaican parents and with Jamaican values so they're Jamaican (personal communication, July 25, 2015)

A.M. (male, 35) added a personal objection to the specific cultural elements that people use to identify Jamaicans:

It seems like we are identified by the entertainment that we bring. It's a pet peeve of mine because no other culture is defined that way. Why are we defined by our music, the way we talk and our athletics? It seems like that's all we have to offer... (personal communication, July 25, 2015)

Visiting Jamaica. Most participants visited Jamaica throughout their childhood and continue to do so during adulthood. The participants explained that they visit Jamaica primarily to visit extended family members who reside there. One person insisted that it is necessary to 
visit Jamaica in order to know what it means to have a Jamaican identity because a true portrayal is not available in Canada. W (female, 35) stated:

There's actually been some Canadian-born kids of Jamaican parentage that have never been to Jamaica. I think for them, it is a struggle for them to know what it means to identify with the Jamaican community outside of their own parents or families. It's not exactly what a lot of the media has portrayed here or even what a lot of the Canadians here portray Jamaicans to be (personal communication, Jul y 25, 2015).

$\mathrm{G}$ (female, 29) agreed with this opinion by sharing that her first visit to Jamaica occurred during adulthood and it provided her with a truer representation of the Jamaican culture. She acknowledged that the trip exceeded her expectations and provided her with a love for Kingston, Jamaica.

Upon visiting Jamaica, $\mathrm{X}$ (male, 35) developed the understanding that being raised in Jamaica is different to being raised in Canada with Jamaican ideals. He also expressed the difference between the Jamaican and Canadian societies by pointing out that Jamaica is "laidback" while Canada has a "rush-rush" culture. He stated:

It pretty much set a sense of Jamaican culture when I came back here [to Canada] but when I go there [to Jamaica], I sort of see that even though I grew with a lot of Jamaican ideals and culture, I didn't grow up the same way that they grew up (X, personal communication, July 25, 2015)

Through these statements, the participants indicated that visiting Jamaica is a necessary part of understanding the Jamaican identity. It allows the second generation to experience the culture in its most authentic form. 


\section{Being Canadian}

In response to the question about being Canadian, the participants highlighted their birth and residence as the primary definition of being Canadian. Aspects of inclusion/exclusion were identified in the responses to this question. Initially, most participants were unsure of what being Canadian means. X (male, 35) admitted that:

No one really identifies with Canada because it's just hard to identify with this country. Pretty much, it happens when someone does greatness in sports or something (personal communication, July 25, 2015).

W (female, 35) disagreed by explaining what being Canadian meant to her:

The way I try to identify with Canada is by trying to locate where a lot of the black Canadians have come from. I try to learn a little bit about the history about how they migrated. My parents are part of that history because they migrated to Canada but the other black Canadians who are here and have made a mark, how did they migrate, where did they migrate to? Where did the shift happen? That's how I try to identify with being Canadian (personal communication, July 25, 2015).

E.R. (female, 34) also provided her own definition of being Canadian by stating that: Being Canadian, I define my history as growing up in my hometown. My parents struggled to live here, I don't necessarily think about the black icons; I just think of my life here in Canada (personal communication, July 25, 2015).

The remaining two participants had responses which varied between the three responses highlighted. Being Canadian was also defined according to Canada's multiculturalism policies. A.M. (male, 35) highlighted that defining a Canadian identity can be difficult because: 
In Canada, there are people who are immigrants who kept their culture so there are a lot of people who emigrated from Jamaica and when they have their kids, they still raise them as if they were in Jamaica (personal communication, July 25, 2015).

He further mentioned that,

It is kind of hard to be a Canadian when the typical Canadian [a white person] doesn't look at me as Canadian. They always ask "hey, where are you from?" (A.M., personal communication, July 25, 2015)

In instances where participants experienced feelings of exclusion because they were asked where they are from, they saw being Canadian as a means of achieving inclusion in the Canadian society. G (female, 29) explained:

It depends on who asks... If it's a white person who asks me, I'm saying, "I'm Canadian... where are you from?"... Depending on who asks, there can be a lot of intention behind that question (personal communication, July 25, 2015).

\section{Sense of Belonging}

Generally, the participants feel a sense of belonging to Canada because it is where they were born and raised. More importantly, the participants felt a stronger sense of belonging to the Jamaican-Canadian society than to the Canadian society. E.R. (female, 34) insisted that:

There is a society here... a Jamaican-Canadian society. It is quite defined here in Toronto.

There are people who are born in Jamaica or whose parents are Jamaican and we combine the two as Jamaican-Canadians (personal communication, July 25, 2015).

As E.R. explained, the Jamaican-Canadian society was developed by persons of Jamaican ancestry who are Canadian-born or emigrated from Jamaica. The experiences of both groups 
provided members with opportunities to relate to each other. As a result, a cultural community is maintained which blends the Jamaican heritage into the Canadian society. X (male, 35) stated:

There are so many Jamaicans who migrated in the 70 s and 80 s. As the second generation, we learnt that there's a whole bunch of us together which sort of helps define it. It started out as an 'us versus them' sort of thing but now they [Jamaicans who migrate] are getting more used to this culture, getting more used to the cold. However, we all have this experience, we all feel similar so let's build this culture, let's build this second generation. We're not fully Jamaican like the ones over there [in Jamaica] because we can't live that laid back kind of lifestyle and survive in this horrible, horrible, wintery country (X., personal communication, July 25, 2015).

These respondents generally feel a sense of belonging to the Canadian society because they are free to maintain a cultural identity with their parents' homeland.

While Canada's multiculturalism policies encourage inclusion in Canada, the participants noted that they do encounter moments of racism and prejudice. Two participants explained that there is a fear of being stereotyped when they identify with their Jamaican ancestry. Depending on the setting, the participants experienced feelings of not belonging because of their race and cultural upbringing. They are aware of the negative traits associated with the Jamaican culture; for example, they are expected to be ignorant, aggressive, loud or weed-smokers.

Even if it is among other black Canadians it also depends too because you get stereotypes among other black Canadians too, if you say that you're Canadian-Jamaican heritage (W, personal communication, July 25, 2015).

One participant shared that he was encouraged to blend into the dominant Canadian society by limiting his use of Jamaican patois in non-Jamaican settings. This was regarded as a 
means of "survival" since it allowed the participant to limit the possibility of being prejudged and stereotyped by "white Canada". X (male, 35) explained:

My mum wouldn't let me use patois outside the house until it was after 9 p.m. She said, "You cannot speak patois to anyone, anywhere". We lived in a more Jewish neighborhood so the schools we went to were a little multicultural but still was predominantly Jewish white. She said that she didn't want us to be classified or anything like that. She was always paranoid that we would be classified or stereotyped. She said that we should speak proper to those people but when you're speaking to your cousins, it's okay but just don't speak patois outside of the house. When you answer the phone, don't speak patois, just answer properly, figure out who it is and then go on from there. (personal communication, July 25, 2015).

Participants also highlighted that Jamaican cultural events are separated from mainstream society. In the discussion about attending cultural events in the GTA, the participants agreed that it was sometimes difficult to attend festivals because of the festivals' locations:

Jambana is all the way outside the city limit, you have to have a car. It also costs more money to get in. The feeling is not the same as it was when I was a teen or early 20 s (E.R., personal communication, July 25, 2015).

To this statement, $\mathrm{X}$ (male, 35) enquired from the other participants:

To speak on that, in your own opinion, do you find that the city of Toronto and the GTA seems to be pushing a lot of the black centric events into corners or outside the city and not issuing permits? (personal communication, July 25, 2015) 
Everyone agreed that there are many instances where Caribbean events and black-centric events are excluded from mainstream society. They also felt that the events are positioned to compete with each other.

Despite these instances of exclusion, the participants still feel a sense of belonging within the Canadian society because:

This is all we know... well, it's not all we know but this is WHAT we know. If you take me and put me in Jamaica, I'd be ok but it is not really what I know. If you take me and put me in a different country, I may get around but here is where I know, this is home (A.M., personal communication, July 25, 2015)

\section{Identifying Oneself}

The participants identified themselves according to their upbringing, ancestry and sense of belonging. The responses show that the participants maintain hybrid identities by merging their cultural identity with their national identity.

If someone asks me where I am from, I'll tell them that I'm Canadian but if someone asks me what my ethnicity or my heritage is, then I'll acknowledge that my background is Jamaican. That's how I identify with that [my Jamaican background]... I love the Jamaican culture, I love what my parents have brought to me in the sense of awareness but at the end of the day, I am Canadian (W, personal communication, July 25, 2015).

The participants also mentioned that their identity alternates depending on the social setting that they are in:

Yea, it all depends on the group that I'm in, in the certain period of time. So if I'm with, it's funny because if I'm with a bunch of people who aren't Jamaican, then I'm Jamaican. 
But if I'm with people who are Jamaican then, I'm not Jamaican because I was born here [in Canada] and raised here and all that stuff (A.M., personal communication, July 25, 2015).

Not one participant identified solely as Jamaican or Canadian, instead, these identities were hyphenated to create a merged identity i.e. Jamaican-Canadian or Canadian-Jamaican. One participant did not limit her identity to the cultural and national aspects; rather, she included her racial identity in her label. G (female, 29) stated:

I'm a black woman who was born In Canada to Jamaican parents. That's how I define myself so I am Afro-Canadian Jamaican. I am black... my race is important (personal communication, July 25, 2015).

When asked to place their racial, cultural and national identities in order of importance, two participants agreed that their national identity is first while two selected their racial identity. A.M. (male, 35) was unsure and identified the complexity of multiple identities:

I don't know. I am struggling with this one. What first comes to my mind is that I'm black; I'm a black person who was born in Canada, Jamaican. Then I'm thinking that my parents are Jamaican, my ancestry is Jamaican and I'm Canadian, I'm black and then I'm thinking.. I was born here. If you want me to list it in order, I'm struggling with that right now. As a black community, I feel like we aren't united so I want to try and bring that unity so I want to be seen as a black person but I don't know if that's first. (personal communication, July 25, 2015)

Although the participants placed their national and racial identities first, they expressed their desire to raise their children with a sense of "Jamaicanness". The family values, work ethic 
and love for Jamaican food were among the aspects of the Jamaican culture mentioned for this purpose. 


\section{Analysis and Discussion}

The results unveiled responses which allowed me to answer the research questions: i) What constitutes cultural transnationalism in the Jamaican community? ii) How do second generation Jamaicans in the GTA develop their identities and what impact does cultural transnationalism have on this process?

\section{Cultural Transnationalism in the Jamaican Community}

The focus group revealed cultural aspects that the participants deemed valuable in the Jamaican community. Some of the results confirm findings from previous research on second generation identity. As Mordecai and Mordecai (2001) noted, Jamaican art, language and social customs are important aspects of the Jamaican culture and identity. In accordance with Mordecai and Mordecai's claim, the participants were asked about their affiliation to Jamaican food, language, music and cultural events, in an attempt to locate their 'Jamaicanness'.

However, there are also areas where other researchers' findings are refuted. The responses revealed that the aspects of culture identified by Mordecai and Mordecai (2001) are not considered primary indicators of a Jamaican identity; rather, the participants insisted that cultural values and ancestral pride are most important. A second area of parting with previous research also emerged. Participants were asked about their visits to Jamaica. While Lee (2011) has suggested that actual mobility is not necessary for transnationalism to occur, all participants insist that visits to Jamaica provided them with a deeper understanding of the Jamaican culture. As a result, the ties deemed most valuable for cultural transnationalism include the proud awareness of Jamaican ancestry, the maintenance of cultural values and periodic visits to Jamaica. 


\section{Second generation Jamaican Identities and Cultural Transnationalism}

The participants expressed that their identities were created based on their cultural upbringing and their life experiences in Canada. Three major themes arose from the discussion: i) Group-based identity v role-based identity; ii) Cultural upbringing, ancestral pride and hybrid identities; and iii) Belonging, exclusion and survival. These themes will be analyzed below, using the social identity theory, the identity theory, and other relevant perspectives.

Group-based identity v role-based identity. The social identity theory states that although the self contains two levels of identity (personal and social), the personal level is overridden by the social/group-based identity (Stets \& Burke, 2000). The group-based identity is developed when the individual conceptualizes his/her identity according to the attributes of a group. Turner et al (1987) explained that "when most of the actors in a category hold the same perceptions, those perceptions are mutually reinforced, and group formation is the result" (as cited in Stets \& Burke, p.227). In this study, there were instances where the participants displayed elements of a group-based identity. For example, the participants understand and agree that they are second generation Jamaicans who are expected to abide by a prescribed set of ideals provided by their ethnic/cultural group. Acceptance of this indicates that the participants categorize themselves according to a sense of group-based identity. For example, as second generation Jamaicans, the participants highlighted that they were raised with a strong work ethic and as a result, are expected to excel academically and career-wise. Although this perception is instilled by the participants' families, it can be seen as an expectation of the larger cultural community. 
As $G$ (female, 29) pointed out, a strong work ethic and the desire for multiple jobs is considered "natural" and is regarded as something that Jamaicans did. She further explained that other Jamaicans around her had a major role in embedding this trait into her cultural identity. She said,

I started working when I was 12 by choice because it was so natural... My parents, my aunts... everybody was always working. I didn't feel busy enough so I did another job (personal communication, July 25, 2015).

The acceptance and promotion of a strong work ethic and other cultural values emphasizes the importance of the Jamaican group-based identity to the participants; however, it was not their only focus.

While the participants were raised according to Jamaican culture and customs, the results show that the participants also identify with their Canadian nationality. As a result, the hybrid sub-group, 'Jamaican-Canadians' was created and became the preferred group-based identity for many interviewed. This indicates that the participants are likely to identify with a group which encompasses elements of their cultural and national identities. Within this hybrid group, the participants' identities became fluid and adaptable. When this fluidity of identity occurs, the uniformity of perception which exists in the group-based identity is challenged and the participant allows his/her role-based identity to dominate (Stets \& Burke, 2000). In the rolebased identity, individuals negotiate their roles through interaction with others. Many participants mentioned that their identity alternated depending on the circumstances and the groups that they were interacting with. This interaction with others ultimately produces the assignment of many roles and each role is given a corresponding identity to be used in different situations (Stets \&Burke, 2000). Additionally, Stryker (2001) suggests that individuals may have 
as many identities within the self, to support the role relationships in which they participate. This multiplicity of identities was recognized when the participants were asked about feeling Jamaican. In response to whether or not she feels Jamaican, W (female, 35) stated that:

It depends on the circumstances, I mean, if I'm at school or work or among social groups, I'm Canadian. If maybe at a parade or an event, and I feel, I guess feel more drawn or patriotic towards my parents' heritage or background [Jamaican] (personal communication, July 25, 2015).

Her response demonstrates that multiple identities are present and are portrayed in relevant situations.

Although the role-based identity may override the group-based identity and vice versa, it is important to note that both levels of identity exist simultaneously within the self. Stets and Burke (2000) insist that each person belongs to a group and occupies a role within that group. Ultimately, the individual maintains a social identity, as well as, a role identity and these two cannot be easily separated. Stets and Burke (2000) purported that,

People are tied organically to their groups through social identities; they are tied mechanically through their role identities within groups. A full understanding of society must incorporate both the organic/group and the mechanical/role form because each is only one aspect of society that links to individual identities in separate but related ways (p. 228).

As a result, I propose that both theories are applicable to the construction of second generation Jamaican identities. The data revealed that the levels of identity within the self do not always dominate each other; rather they may intersect at times. This is supported by various statements from the participants. For example, G (female, 29) explained that her identity is fluid 
and intersect at different points. She said: "For me Jamaican is always there whether it is stronger at the moment or a little less" (personal communication, July 25, 2015). Similarly, other participants have expressed a group-based identity although they are engaged in portraying role identities, for example, at school and work. This indicates that a sense of the group-based identity exists throughout the portrayal of the role identities.

The identity which dominates during relevant situations however, is affected by many factors and one of these is the salience/significance of the identity. Hogg et al (1995) explained that the significance of an identity will increase the likelihood of the identity being portrayed or selected during a situation. The significance of an identity and the commitment to this identity are increased through social relationships and interactions. The participants' relationship to their Jamaican heritage and Canadian nationality is explained in the following sections and will show how the strength of this relationship has impacted their overall choice of identity.

Cultural upbringing, ancestral pride and hybrid identities. Canada's multiculturalism policies encourage cultural communities to flourish and maintain the culture of the home country (Plaza, 2006). As a result, the second generation are exposed to and influenced by the parents' ancestral culture in a variety of ways. The participants' relationships to aspects of cultural upbringing (values, norms, food, music, language and attendance to cultural events) is reflective of Plaza's view that the second generation "live between two worlds" (2006, p. 213). Although the participants are Canadian-born, most identified themselves as both "Jamaicans and Canadians", which shows that they consider their cultural upbringing a major part of their identity. Plaza (2006) attributes this recognition as a response to marginalization in the Canadian society. He explained that, 
To a large extent, one-and-a-half-generation and second generation Caribbean

Canadians have found themselves in the position of the "marginal man" while growing up (Plaza, 2006, p. 215)

Plaza (2006) further explained that the "marginal man" occurs when an individual exists on the margin of separate groups or cultures. As a result, the individual cannot completely identify with either group or culture. In this case, the individual may create their identity by merging aspects of both cultures. In his study on the Caribbean second generation, Plaza (2006) noted that the individual also engages in creating ethnic boundaries during the hybrid identity process and can choose the aspects of culture that s/he deems valuable to his/her identity. This process allows individuals to "determine who they are, what they are, and how they feel they fit into the existing dominant culture" (Plaza, 2006, p. 215).

Some ethnic boundaries are visible in the responses given by the participants of my study. Some participants stated that they rejected some aspects of the Jamaican culture because it is not necessary for the definition of their identity. For example, A.M. (male, 35) mentioned that he is not a fan of Jamaican music and he is not interested in attending cultural events. For him, his ethnic boundary is limited to aspects such as Jamaican cultural values, a love for Jamaican food and possession of Jamaican ancestry. Others felt that their hybrid identity should be inclusive of ancestral pride and frequent visits to cultural events and Jamaica.

Although the participants created a hybrid identity using their Jamaican and Canadian identities, it is noted that this merging is not the second generation's only option. Some participants pointed out that their American-born cousins who live in the U.S. are less likely to adopt a Jamaican cultural identity and have adopted an "African-American response in which they assimilate into the culture around them" (Plaza, 2006, p. 213). 
A lot of my first cousins who were born in the States have adapted to the American lifestyle, while in Canada, if you're born here, and all my cousins in Canada, they identify more with the Jamaican culture (A.M., personal communication, July 25, 2015). A merging of the 'African/black identity' and Canadian identity was also evident in my focus group. W (female, 35) explained that she identifies with Canada by learning the history of Black Canadians and while she accepts her Jamaican heritage, it is also important for her to identify as Black Canadian. She said:

The way I try to identify with Canada is by trying to locate where a lot of the black Canadians have come from. Sometimes I make the mistake of thinking that every black Canadian is from the Caribbean and I get a culture shock when someone says "no, I'm 4th generation Canadian". So, I try to understand the history of migration of black Canadians into Canada to identify myself more with being [Black] Canadian (W, personal communication, July 25, 2015).

Belonging, exclusion and survival. Participants expressed that they feel a sense of belonging to Canada because they are born and raised here. Although they stated this, it is recognized that their sense of belonging does not go unchallenged by instances of exclusion. "White Canada," the term that the participants used to identify persons of Anglo-Saxon ancestry in Canada, is considered to be the description of "typical Canadian" because of the group's dominance in Canadian society. In an interview with immigrants who acquired Canadian citizenship, Howard (1998) asked about the characteristics of a typical Canadian. While some respondents attempted to answer through a multicultural lens, many admitted that a typical Canadian refers to the dominant group and its Anglo-Saxon culture. 
Adult immigrants frequently said their stereotype before arriving in Canada was of white people of English or Scottish background. This stereotype was usually presented merely as a fact, without any particular rancour. Immigrants also occasionally referred to 'Canadians' as people who played hockey, skied or skated (Howard, 1998, p. 139). With regard to my study, the participants felt that their Canadian identity, status and belonging were continuously questioned by predominantly "typical Canadians". Participants also shared that they often felt "prejudged" or "stereotyped" by others when they revealed their Jamaican ancestry and felt discriminated against because of their skin color or race. One participant highlighted that "white Canada" is more likely to question one's origin if one is black or of the African race. She said: "If you're black, they want to know where you are from..." (W, personal communication, July 25, 2015). The participants expressed that although their race is a major reason why their origin is questioned; the prejudice exists beyond racial compositions. One participant shared that other black Canadians also stereotype Jamaican-Canadians because of their Jamaican heritage and this stereotyping continuously adds to the occurrence of exclusion.

Despite the adoption of multiculturalism policies to facilitate inclusion in the Canadian society, cultural groups and minorities are faced with constant episodes of racism. While the impact of racism on one's identity is beyond the scope of this paper, the process of exclusion itself can be explained through the perspective of social identity theory. The theory states that society is divided into social groups which are in constant social comparison with each other (Hogg et al, 1995). When social comparison occurs, the self identifies persons with similar attributes as a member of the in-group and others as members of the out-group. This results in the occurrence of inclusion and exclusion or an 'us versus them' mentality whereby the outgroup is viewed negatively (Stets \& Burke, 2000). Among the participants of my focus group, 
there were differing views on coping with this phenomenon. Some were encouraged by their families to "be very proud of who [they] are and not care about what other people had to say" (G., personal communication, July 25, 2015) while others were encouraged to adjust to the preferred behavior of the dominant group within the group's presence. The latter is regarded as a means of survival whereby the individual is forced to become "chameleon-like". X (male, 35) explained that this adaptation is necessary for survival in the Canadian society:

...just [be] cautious of yourself. Don't let anyone pre-judge you, don't present an opportunity where someone could bring you down based on your cultural upbringing. It's like survival. We're still being true to the culture that we share but realize that other people don't share the same values and they will judge you based on your heritage, they will judge you based on your skin color, they will judge you based on all sorts of things. To minimize that, don't go speaking patois to some people. Especially to white Canada, they think down upon Jamaicans. They think that patois is a lower language and means that you are uneducated. Don't let them have that thought about you right off the bat, just do what you got to do, survive, speak their proper English to them so that they can be happy (personal communication, July 25, 2015).

Overall, the participants have shown that as second generation Jamaicans they have embraced their cultural and national identities by creating a place where there is a sense of belonging to the Jamaican culture and the Canadian nationality. In this case, "place is a trope that analyzes how social actors capture a sense of belonging” (Hall, 2010, p. 133). The JamaicanCanadian identity provides a sense of belonging to those of Jamaican ancestry who are Canadian-born, as well as those who are Jamaican-born who immigrated to Canada. This place allows individuals to maintain both Canadian and Jamaican identities and Hall (2010) suggests 
that in this place, the use of Jamaican language, food, art, music, norms and values serve as "crucial cultural tools to fend off displacement" (p. 134). 


\section{Conclusion}

This study set out to discover what constitutes cultural transnationalism in the Jamaican community and how cultural transnationalism affects the identity process of second generation Jamaicans in the GTA. To gather data for this research, a focus group interview with five second generation Jamaicans was conducted. The interview was recorded and transcribed, and data was analyzed using relevant theories. The data revealed that the second generation lives in a transnational space where they are grown according to Jamaican customs and values. The participants' relationship to Jamaican food, art, language and cultural events were examined and participants revealed that these aspects are considered secondary to a Jamaican identity. They explained that the greatest aspect of cultural transnationalism among the second generation exists in the maintenance of cultural values, customs and in the pride of their ancestry.

The participants also highlighted that the second generation is likely to adopt a hybrid identity which merges their Jamaican heritage with their Canadian nationality. This fusion means that the participants are able to maintain a fluid identity which allows them to display different identities in different situations. Theoretically, the existence of multiple identities is attributed to the identity theory which states that the self behaves according to the role(s) it is prescribed. Nonetheless, at times, the participants also conceptualized their identity by categorizing themselves according to group-based attributes, which shows that the social identity theory is also applicable to the creation of their identities.

These second generation Jamaicans do not feel a complete sense of belonging to either society (Jamaican or Canadian); rather, they have created a space where they simultaneously belong to both societies. Hence, the Jamaican-Canadian society is representative of a transnational space where the second generation feels a strong sense of belonging. 'Jamaican- 
Canadian' is the preferred term used to identify these second generation Jamaicans in Canadian society and this label demonstrates that they are strongly influenced by both their cultural upbringing and nationality.

Alternatively, this study shows that although ancestral pride is a great aspect of cultural transnationalism, the second generation may hesitate to identify with their ancestral community because of fear of exclusion. Although Canada has adopted a multiculturalism policy to facilitate the inclusion of different cultures, minority groups are still faced with instances of prejudice and racism. Studies like this one may help uncover terminologies and stereotypes which may encourage exclusionary feelings among the Canadian-born children of immigrants. For example, the participants felt that they are constantly judged against the definition of a 'typical Canadian' which refers to Anglo-Saxon attributes and culture. As a result, they felt like they were predominantly unaccepted and are considered less Canadian in Canadian society. To decrease this occurrence, an all-inclusive, postmodern definition of what it means to be Canadian should be created and promoted. This definition should refer to a Canadian's multicultural characteristics so that a greater sense of inclusion is fostered within Canadian society. Furthermore, an understanding of the relationship between citizenship, diversity and transnationalism should also encourage policy-makers to use more inclusive terminology and meanings. Once these changes are implemented, the second generation may be encouraged to openly view and manifest their Canadian identity beyond Canadian birth and residence. Hyphenated identities will no longer require an individual to merge their cultural and national identities due to 'marginal man' feelings; rather, it will be created to reflect the diversity of a Canadian identity. 


\section{Limitations and Further Research}

The study was successful in answering the research questions posed; however, I faced many limitations. Due to the scope of my paper and time constraints, I was unable to delve further into sub-themes and use a large research sample. For future research, I propose five areas of further exploration:

i) My research sample was limited to the opinions of five participants of one race with similar ages and social status. For future research, to get a complete understanding of the Jamaican second generation's identity process, it would be helpful to recruit persons of different races, social classes and age ranges. It may also be more efficient to recruit a larger number of participants and provide an additional research method. For example, personal interviews may allow the researcher to go deeper into some of the additional issues mentioned in the focus group interview. Multiple focus groups in different locations throughout the GTA will also allow the researcher to reach a larger population.

ii) Future research should also include more discussion about the visiting habits of second generation Jamaicans since it would be useful to discover whether or not this habit increases or decreases as an individual gets older. Also, the existence of economic and political transnational habits should be explored to determine if second generation Jamaicans feel the need to be involved in Jamaica's current affairs.

iii) Despite the ability to acquire dual citizenship (Jamaican and Canadian) and their strong affiliation to the Jamaican heritage, all participants were holders of single Canadian citizenship. Future studies should question this occurrence to determine whether second generation Jamaicans feel an obligation to maintain single citizenship with the country of their birth. 
iv) It would be interesting to discover whether or not the impact of transnationalism on the identity process differs for second generation Jamaican males and females. Future studies should explore these possible differences by conducting gender-based focus groups which will identify the aspects of transnationalism that second generation Jamaican males and females incorporate into their identity process.

v) Lastly, it is important to analyse the impact that racism has on the identity process of second generation Jamaicans. Although the impact of racism on the identity process could not be adequately discussed in this paper, the data suggests that it should be examined deeply. Scholars such as Hernandez-Ramdwar (2005) discussed the negative stereotyping and monolithic perception of the Caribbean identity, held by others in Canadian society. Subsequent research in that area can focus on the influence that racism and negative stereotyping have on the identities of second generation Jamaicans. 


\section{Appendix 1}

Table 1

Participants' Demographics from Focus Group

\begin{tabular}{|c|c|c|c|c|c|c|c|}
\hline Name & $\underline{\text { Gender }}$ & $\underline{\text { Age }}$ & $\underline{\text { City/Town }}$ & $\underline{\text { Citizenship }}$ & $\underline{\text { Ancestry/ }}$ & $\underline{\text { Education }}$ & $\underline{\text { Jamaican }}$ \\
\hline A.M. & Male & 35 & Toronto & Canadian & Black & University & 2 \\
\hline E.R. & Female & 34 & Scarborough & Canadian & Jamaican- & University & 2 \\
\hline G. & Female & 29 & Markham & Canadian & Jamaican/Black & University & 2 \\
\hline W. & Female & 35 & Ajax & Canadian & Jamaican & University & 2 \\
\hline X. & Male & 35 & Toronto & Canadian & Canadian & University & 2 \\
\hline
\end{tabular}




\section{References}

Burke, P. J., \& Reitzes, D. C. (1981). The link between identity and role performance. Social Psychology Quarterly, 44(2), 83-92. Retrieved from http://www.jstor.org.ezproxy.lib.ryerson.ca/stable/3033704?pqorigsite $=$ summon $\&$ seq $=1 \#$ page_scan_tab_contents

Burke, P. J., \& Stets, J. E. (2009). Identity theory Oxford University Press.

Hall, M. (2010). Re-constituting place and space: Culture and communication in the construction of a Jamaican transnational identity. Howard Journal of Communications, 21(2), 119140. doi:10.1080/10646171003727425

Hall, S. (1996). Introduction: Who needs identity? In S. Hall, \& P. Du Gay (Eds.), Questions of cultural identity (pp. 1-17). London; Thousand Oaks, California: Sage

Hernandez-Ramdwar, C. (2005). Challenging negative stereotyping and monolithic constructions through Caribbean Studies. Caribbean Quarterly, 51(3/4), 77-85. http://doi.org/10.2307/40654521

Hogg, M. A. (2007). Uncertainty-Identity theory. (pp. 69-126) Elsevier Science \& Technology. doi:10.1016/S0065-2601(06)39002-8

Hogg, M. A., Terry, D. J., \& White, K. M. (1995). A tale of two theories: A critical comparison of identity theory with social identity theory. Social Psychology Quarterly, 58(4), 255269. Retrieved from http://www.jstor.org.ezproxy.lib.ryerson.ca/stable/2787127?pqorigsite $=$ summon $\&$ seq $=1$ \#page_scan_tab_contents

Howard, R. E. (1998). Being Canadian: Citizenship in Canada. Citizenship Studies, 2(1), 133152. doi:10.1080/13621029808420674

Isin, E.F., \& Wood, P.K. (1999). Citizenship and identity. London: Sage. 
Jedwab, J. (2007). Dually divided? The risks of linking debates over citizenship to attachment to Canada. International Journal, 63(1), 65-77.

Kasinitz, P., Waters, M. C., Mollenkopf, J. H., \& Anil, M. (2002). Transnationalism and the children of immigrants in contemporary New York. In M. C. Waters, \& P. Levitt (Eds.), The changing face of home: The transnational lives of the second generation (pp. 96-133) Russell Sage Foundation.

Lee, H. (2011). Rethinking transnationalism through the second generation. The Australian Journal of Anthropology, 22(3), 295-313. doi:10.1111/j.1757-6547.2011.00150.x

Leitner, H., \& Ehrkamp, P. (2006). Transnationalism and migrants' imaginings of citizenship. Environment and Planning A, 38(9), 1615-1632. doi:10.1068/a37409

Mordecai, M., \& Mordecai, P. (2001). Culture and customs of Jamaica. Westport, Connecticut; London: Greenwood Press.

Neuman, W.L. (2011a). The meanings of methodology. In Social research methods: Qualitative and quantitative approaches. (7th ed., pp. 90-122). Boston: Allyn and Bacon.

Neuman, W.L. (2011b). Field research and focus group research. In Social research methods: Qualitative and quantitative approaches. (7th ed., pp. 420-463). Boston: Allyn and Bacon.

Neuman, W.L. (2011c). Strategies of research design. In Social research methods: Qualitative and quantitative approaches. (7th ed., pp. 163-197). Boston: Allyn and Bacon.

Neuman, W.L. (2011d). Analysis of qualitative data. In Social research methods: Qualitative and quantitative approaches. (7th ed., pp. 507-541). Boston: Allyn and Bacon. 
Neuman, W. L., \& Robson, K. (2012). Qualitative and quantitative sampling. Basics of social research: Qualitative and quantitative approaches (2nd Canadian ed., pp. 129-152) Pearson Allyn and Bacon.

National Household Survey profile, Canada, 2011. (2014). Retrieved August 24, 2015, from http://www12.statcan.gc.ca/nhs-enm/2011/dp$\mathrm{pd} /$ prof/details/page.cfm?Lang=E\&Geo1=PR\&Code1=01\&Data=Count $\&$ SearchText=ca nada\&SearchType $=$ Begins $\&$ SearchPR $=01 \& A 1=$ All $\& B 1=$ All $\&$ Custom $=\&$ TABID $=1$

Plaza, D. (2006). The construction of a segmented hybrid identity among one-and-a-halfgeneration and second generation indo-caribbean and african caribbean canadians. Identity, 6(3), 207-229. doi:10.1207/s1532706xid0603_1

Portes, A., Guarnizo, L., \& Landolt, P. (1999). The study of transnationalism: Pitfalls and promise of an emergent research field. Ethnic and Racial Studies, 22(2), 217-237. doi:10.1080/014198799329468

Somerville, K. (2008). Transnational belonging among second generation youth: Identity in a globalized world. Journal of Social Sciences, 10(1), 23-33. Retrieved from http://www.krepublishers.com/06-Special\%20Volume-Journal/JSS-00Special\%20Volumes/JSS-SV-10-Youth-Migration-Web/JSS-SV-10-03-023-08Somerville-K/JSS-SV-10-03-023-08-Somerville-K-Tt.pdf

Stets, J. E., \& Burke, P. J. (2000). Identity theory and social identity theory. Social Psychology Quarterly, 63(3), 224-237. Retrieved from http://www.jstor.org.ezproxy.lib.ryerson.ca/stable/2695870?pqorigsite=summon\&seq=1\#page_scan_tab_contents 
Stryker, S., \& Burke, P. J. (2000). The past, present, and future of an identity theory. Social Psychology Quarterly, 63(4), 284-297. Retrieved from http://www.jstor.org.ezproxy.lib.ryerson.ca/stable/2695840?pqorigsite=summon\&seq=1\#page_scan_tab_contents

Stryker, S. (1980). Symbolic interactionism: A social structural version Benjamin/Cummings Pub. Co.

Stryker, S. (2001). Identity theory. In E. F. Borgatta, \& R. J. V. Montgomery (Eds.), Encyclopedia of sociology (2nd ed., pp. 1253-1258). New York: Macmillan Reference USA.

Tajfel, H. (1974). Social identity and intergroup behaviour. Social Science Information, 13(2), 65-93. doi:10.1177/053901847401300204

Wong, L. L. (2007). Transnationalism, active citizenship, and belonging in Canada. International Journal, 63(1), 79-99. 